\title{
Diego Bonetto* \\ Framing Bottled Water: A Comparative Reflection on the Legal Paradigm
}

DOI 10.1515/gj-2015-0017

Abstract: The work compares two apparently different legal frameworks governing bottled water to highlight the underlying convergence of their rhetorical underpinnings. In particular, it looks at the law regulating the exploitation of water destined to bottling in India and Italy. Through these two examples this work wants to show how in both countries, which may serve as, respectively, a Global South and a Global North examples as to their position in the worldwide allocation of economic wealth and labour, the regulations treat water as a commodity focusing on the aspects concerning its commercialization by private companies.

Keywords: water, commons, property, natural resources, privatization

\section{Introduction}

The purpose of this work is to compare two apparently different legal frameworks governing bottled water in order to highlight the underlying convergence of their rhetorical underpinnings. In particular, it looks at the law regulating the exploitation of water destined to bottling - either in the form of plain bottled water or water used to produce soft drinks - in India and Italy. Through these two examples this work wants to show how in both countries, which may serve as, respectively, a Global South and Global North examples as to their position in the worldwide allocation of economic wealth and labour, ${ }^{1}$ the regulations

1 The legal systems of India and Italy have been chosen because both countries registered the emergence of social movements on water related issues recently. The water movements brought to numerous active protests in India and to a referendum on the privatization of water services in Italy. The latter is chosen as representative of the Global North for the contradiction that it exemplifies between the richness of high quality water available and the impressive quantity of per-capita bottled water consumption. In fact, Italy is the third country in the world for percapita consumption of bottled water (Source: Beverage Marketing Corporation). India, instead,

*Corresponding author: Diego Bonetto, Sciences Po - Law, 13, rue de l’Université Paris 75007, France; University of Turin - Law, Lungo Dora Siena 100/A Turin TO 10154, Italy,

E-mail: diego.bonetto@sciencespo.fr 
treat water as a commodity focusing on the aspects concerning its commercialization by private companies.

As discussed below, the diversity in the black letter of law that characterizes the two countries is overcome by a similarity in the way in which bottled water is eventually appropriated and exploited by private actors. Such condition derives from a dangerous misrepresentation of the nature of the resource and of its property regime, a situation that entails a series of social, cultural and economic consequences that differ in the countries considered and that are not clearly evident when analysing the legal datum.

For what concerns Italy, the regime produced by legislative and judicial interventions on mineral water creates a de facto expropriation of local communities of their water resources in favour of private companies. The latters realize almost net profits, without any direct compensation but - what is more important - also with no regulatory awareness of the inefficient deprivation that lies beneath the current regime.

In India the regulatory regime has even graver consequences. In fact, the current discipline is such that it limits - if not prevent - the access of entire communities to safe water. In addition, the commodification of water and the link between access and economic availability may also create a problem of democracy in the access of social classes whose level of wealth is insufficient for assuring a regular supply of bottled water.

In order to carry the comparative study of the legal frameworks, this article takes into account the positive datum but mainly focuses on two significant cases decided in the two countries. These cases seem to have taken the first step towards a jurisprudential construction of a new paradigmatic framework which reconsiders water destined to bottling by taking into account its broader social role and the social function of the property arrangement applied. The analysis will consider the outcomes and the reasoning of the Courts in relation to their respective contexts. The purpose is to understand which are the real underpinning issues and eventually offer a possible solution.

The first part of the work is thus dedicated to the analysis of the two caselaws - respectively the Uliveto S.p.A. v. Comune di Vicopisano case for Italy and the Perumatty Grama Panchayat v. State of Kerala case for India - and their corresponding legal and cultural backgrounds. The second part highlights the common patterns that the two - only apparently different - regulations present in their judicial enforcement, and the consequences that this common framework have in the two different contexts. Section three shows that the two legal

is representative of those countries where the consumption of bottled water is still low and where the economy of entire communities, based on agriculture, relies on the access to water. 
frameworks rely on a dangerous misrepresentation of water that does not consider the tension between the nature of water as a scarce resource essential to human life and its construction as a commodity suitable of being appropriated and subjected to the market mechanisms of supply and demand. The last section offers some conclusive remarks and concrete proposals for an appropriate redefinition of the two legal systems.

\section{India and Italy: the case-studies}

As mentioned before, India and Italy have been chosen, amongst the legal systems of respectively the Global South and Global North, because of the fervour registered in both countries around the issue of water management. Italy saw the birth of social movements against privatization of water management that brought to the popular referendum of 2011 ended up blocking the privatization process. In India there has been an explosion of social protests against the massive water exploitation brought along by multinational corporations. The most famous example of these protests is, indeed, the Plachimada protest analysed in this article. The aim is thus to analyse the frameworks governing the bottling of water and discuss whether the tensions are linked with similar legal structures or not.

In order not to focus the attention only on the positive legal aspects of the two legal system, I draw on two case-studies that are the Perumatty Grama Panchayat v. State of Kerala case for India and the Uliveto S.p.A. v. Comune di Vicopisano. This allows the inclusion of those aspects of the legal framework that are not the black letter of law but part of the jurisprudential sphere and the consideration of the cultural aspects and the social circumstances taken into account in the decisions.

\subsection{The Plachimada case}

The events concerning the case of Plachimada commenced in the year 2000 when the Hindustan Coca-Cola Beverages Private Limited (the Company), having obtained the required licence by the local authority (the Perumatty Grama Panchayat), ${ }^{2}$ built a plant in Plachimada to produce its brand beverages, such

2 Pursuant to the Constitutional amendments, No.73 and 74 concerning decentralization, the State of Kerala, with the Kerala Panchayat Raj Act in 1994, transferred to the Perumatty Grama 
as Coca-Cola, Fanta etc. It is important to notice that the district where the plant was built, the Palakkad district, represents an important agricultural area. In this area, which is also called the "rice bowl of Kerala", ${ }^{3}$ most of the people make their living by and depend upon agriculture. Moreover the whole agricultural region is highly dependent on ground water and canal irrigation for both agricultural and domestic needs. ${ }^{4}$ As reported by Sujith Koonan "Plachimada is also home to several scheduled castes and scheduled tribes. The villagers are predominantly landless and agricultural labourers". 5

A year after the Company started its pumping activity in Plachimada, the local community began to protest against such important exploitation of water resources. The community claimed that the Company caused a shortage of ground water in the surrounding villages as well as pollution of the little water remained available. The protestors' major demand was the immediate closure of the plants. A number of NGOs joined the agitation and produced reports on the "causes and effects of the deterioration of the ground water quality in Plachimada." 6 There were different reports attributing such events to different causes depending, amongst other things, on the political forces underpinning the emission of the licence.

The legal battle started when the local authority that had released the licence (Perumatty Grama Panchayat) acknowledged the negative impact of the Company pumping activity for the surrounding communities. As a consequence, on April 7, 2003, it refused to renew the authorization for the extraction of ground water to the Company, which then challenged the resolution before the Kerala High Court.

The legal framework concerning the exploitation of ground water in the Indian legal system, the one proper of the State of Kerala and therefore applicable to the case of Plachimada, relies on principles derived from praxis rather

Panchayat the power on water resources burdening the Panchayat with the responsibility to abate the nuisance produced by any industry or factory within its jurisdiction. Accordingly, private operators in order to exploit groundwater for commercial purposes need a licence released by the Panchayat.

3 Jananeethi, Report on the Amplitude of Environmental and Human Rights Ramification by the HCC BPL at Plachimada 1, (Thrissur: Jananeethi, July 2002).

4 C.R. Bijoy, "Kerala's Plachimada Struggle: A Narrative on Water and Governance Right", Economic and Political Weekly, Vol.41, No.41, (2006): 4332-4333.

5 Sujith Koonan, "Groundwater: Legal Aspects of the Pachimada Dispute", in Water Governance in Motion: Towards Socially and Environmentally Sustainable Water Laws, eds. P. Cullet et al. (New Delhi: Cambridge University Press, 2010): 161.

6 Ibid. 
than from positive law. ${ }^{7}$ In particular, it is currently structured around the Kerala Ground Water (Control and Regulation) Act, that was issued in 2002 (hereinafter KGWA). However, the KGWA was not applicable to the case under analysis since it was notified only in 2003 after the Plachimada case already started. Thus, before the introduction of the KGWA, the exploitation of ground water in the State of Kerala was almost unregulated.

The proceeding, initiated by the Company, revolved around the question of whether the Perumatty Grama Panchayat had the power to revoke the licence originally granted to the Company. Pursuant to the $73^{\text {rd }}$ and $74^{\text {th }}$ Constitutional amendment of 1992 and its decentralization policy, the states have the power to explicitly devolve some of their authority to local administrations such as the Panchayat. In the case of water in the State of Kerala, the Kerala Panchayat Raj Act of 1994, "transferred [...] and absolutely vested" ${ }^{8}$ in the Panchayat the power on all water resources, except the one passing through more than one Panchayat. Furthermore, the same Act gives the Panchayat responsibility to abate the nuisance produced by any industry or factory within its jurisdiction. ${ }^{9}$

From the point of legal arguments, the High Court was required to decide whether the Panchayat had the power to revoke the licence, it had to adjudicate the case relying on and balancing two legal principles: the Public Trust Doctrine and the common law principle on ground water rights. On the one hand, the Public Trust Doctrine produces a framework where, as Chhatrapati Singh explains, "the state which holds the natural waters as a trustee, is duty-bound to distribute or utilise the waters in such a way, that it does not violate the natural right to water of any individual or group and safeguards the interest of the public and of ecology (or nature)."10 On the other hand the common law principle on ground water rights states that ground water is considered part of the soil under which it lies and, thus, a chattel belonging to the land with no distinctive character of ownership. ${ }^{11}$

The proceeding ended with the Single Judge of the High Court ruling in favour of the Panchayat and recognizing its power to restrict or prohibit the use of ground water within its jurisdiction. The Judge stated that "in the absence of any law governing ground water [...] the Panchayat and the State

7 See Héctor Garduño, et al., "India Groundwater Governance - Case Study", Water Papers (June 2011), accessed October 28, 2015, www.worldbank.org/water.

8 The Kerala Panchayat Raj Act, 1994, Section 218.

9 The Kerala Panchayat Raj Act, 1994, Section 233A as reported in C.R. Bijoy, "Kerala's Plachimada Struggle: a Narrative on Water and Governance Right”, cit.: 179.

10 Chhatrapati Singh, Water Rights and Principles of Water Resource Management, (Bombay: N.M. Triphati, 1991): 76.

11 Ibid. 
are bound to protect the ground water from excessive exploitation. In other words the ground water under the land of [the Company] does not belong to [it]." ${ }^{12}$ According to rules of praxis the Company should be allowed to exploit the ground water to the normal amount required for the irrigation of crops in 34 acres of plot.

Both parties appealed the decision and the case went before the division bench of the High Court that overturned the decision. The main divergence between the judges seems to be the fact that, unlike the single judge, the division bench held ground water a "private water resource". ${ }^{13}$ Accordingly, the extraction of water by the owner cannot be considered illegal and the division bench does not find any ground for the power of the Panchayat either to limit the exploitation of the company or to revoke the relative licence.

For the purposes of this work the issue of the establishment of the Plachimada Coca-Cola Victims Relief and Compensation Claims Special Tribunal has been deliberately omitted as not relevant for the analysis here conducted. ${ }^{14}$ The main focus in this case is on "the power of the Panchayat to regulate ground water use in its jurisdiction and the right of the land owner to draw ground water from his land." 15 The balance between the two principles was done differently by the single judge and the division bench of the High Court of Kerala. While the former relied more upon the Public Trust Doctrine, acknowledging the power of the Panchayat, the latter weighted more the common law rule and property rights recognizing the Company's right to draw ground water from its property.

The case is now waiting to be assessed by the Supreme Court of India since the Panchayat appealed the verdict of the division bench.

12 See Perumatty Grama Panchayat, Proceeding of the Special Grade Secretary, 27 January 2000, §13.

13 S. Koonan, "Groundwater: Legal Aspects of the Pachimada Dispute”, cit.: 186.

14 On this issue is worth noticing that the State of Kerala, in 2011, established the Plachimada Coca-Cola Victims Relief and Compensation Claims Special Tribunal, recently declared unconstitutional by the Union Home Ministry. The Special Tribunal was constituted pursuant to the bill passed by the Kerala Legislative Assembly, on 24 February 2011, named "Plachimada CocaCola Victims Relief and Compensation Claims Special Tribunal Bill"; for more on this issue see Sujith Koonan, "Constitutionality of the Plachimada Tribunal Bill, 2011: An Assessment”, Law, Environmental and Development Journal, Vol.7, No.2, (2011): 151; and K.A. Shaji, "Centre terms Plachimada Bill Unconstitutional”, The Hindu, January 20, 2015, accessed October 28, 2015. 15 S. Koonan, "Groundwater: Legal Aspects of the Pachimada Dispute”, cit.: 197. 


\subsection{The Italian case}

The second case is Uliveto S.p.A. vs. Comune di Vicopisano Terme.

The case was started by the Uliveto S.p.A., an Italian bottling company and one of the leaders in the Italian market of bottled water that sued the municipality of Vicopisano Terme - the local authority with administrative competence over the source of bottled water - for what it considered to be an excessive determination of the rent that the company had to pay for the licence allowing it to use and bottle the water extracted from the land included in the licence. ${ }^{16}$

Similarly to India the legal framework for the exploitation of ground water for bottling in the Italian legal system is based on licences granted by the public authority to the private operator. In fact, according to the regulatory regime, water is de jure a public property. In a decentralization move the authority has been delegated by the central State to the regions, which can in turn delegate it to the local authorities as in the case of the instant dispute. The matter of this dispute the amount of money paid to extract water - is the most frequent as well as the most relevant in this field in Italy. ${ }^{17}$ However, even though this case is common, it is to some extent important and peculiar because of the decision and the argumentation of the Consiglio di Stato (the administrative supreme court).

In 2011 the municipality of Vicopisano Terme passed a resolution which unilaterally raised the price that Uliveto S.p.A. had to pay for the licence. ${ }^{18}$ The municipality acted according to the power that the regional law of Toscana of 2004, no. 38, conferred to it. ${ }^{19}$ However, the company challenged the Resolution before the regional administrative Court - Tribunale Amministrativo Regionale della Toscana - claiming that such unilateral increase in the price was in breach of the agreement stipulated between Uliveto and the Municipality when the licence had been granted. In its first decision the regional court ruled in favour of the company. The municipality of Vicopisano Terme appealed to the Administrative Supreme Court (Consiglio di Stato) which overturned the verdict.

The Consiglio di Stato dismissed the claim of the company on the ground that the price a private extractor has to pay to the Municipality is composed of

16 Uliveto S.p.A. vs. Comune di Vicopisano Terme, Consiglio di Stato, sez. V, No.1823/2013.

17 See amongst many: Consiglio di Stato (C.d.S.) No.7962/2010, C.d.S. No.4679/2011, C.d.S. No. 4431/2012.

18 The Resolution of the Board of the Municipality of Vicopisano No. 71 of June 17, 2011, unilaterally modified the price that Company had pay for the exploitation of the resource on the base that the determination of the price felt within the power of the public administration and was not part of the contractual agreement.

19 Art. 22 of the Regional law of Toscana of 2004, No. 38, provides that the determination of the price of the licence falls within the power of the competent public administration. 
two elements. One includes all the voices that have been included in the agreement made by the parties at the moment in which the licence was released, which are to be deemed contractual and depending on the will and autonomy of the parties. ${ }^{20}$ The other is the annual rent owed to the municipality for the licence: this, according to the Consiglio di Stato, is determined unilaterally by the authority and has to be determined, amongst other criteria, by the amount of water bottled. This very criterion was the subject of controversy. As a matter of fact, it can provoke a substantial change in the regulation of bottled water as it sets the principle according to which a private company that exploits water has to pay for the amount privatized.

The Administrative Supreme Court affirmed the validity of this criterion and, recalling a previous Decision of the Constitutional Court of 2001, no.65, went on saying that "the principle of free-trade [which was part of the argument with the company] is, in fact, wrongly invoked against instances, of which regions can be interprets too in the subjects in which they have competence, directed not to depress the value of natural resources constituting public patrimony." 21 In its argumentation the Court also affirmed that the Municipality has the power to fix the price of the licence to a value that is proportional to the amount of water that they extract. The administration has the power to "ask for a quid pro quo for privatizations (or, as in this case, for the economic exploitation) of a public good."22

In this case the Court seems to go a step forward in the sense of recognizing the power of the public authority to manage a resource that belongs to the public. However the Court's reasoning still appears to rely on a misleading conceptualization: It recognizes the public ownership of water used for bottling purposes, but it fails to see this water as a 'resource essential to human life' and to dispose an adequate system of compensation calibrated to the proper property regime.

\section{A comparison of the two cases and their legal frameworks}

Having highlighted the main elements of the two cases, this section offers a comparison between them with the aim to point out the similarities of the two systems and highlight in what they differ. The differences are here analysed

20 Uliveto S.p.A. vs. Comune di Vicopisano Terme, Consiglio di Stato, sez. V, No.1823/2013.

21 See Uliveto S.p.A. v. Comune di Vicopisano, Consiglio di Stato, Sez. V, No.1823/2013, (translation by the Author).

22 See Ibid. 
thoroughly: although they appear to be deep at first glance, at a more thorough look, 'they become attenuated'.

The main issue explored here is the property arrangement that lie behind each case. In the Italian scenario the groundwater exploited by private companies for bottling activity is clearly treated as a public property. On the contrary, the legal framework in India is more complex due to a "shortcoming of the common law rules" 23 regulating the subject. As reported by C. R. Bijoy, pursuant to the Indian Easement Act of 1882 the "right to groundwater is linked to the right to land and [entails an] almost absolute ownership of groundwater by the property holders." 24 "The state as an eminent domain has power over natural resources." 25 Thus, the private ownership of the land, according to the common law, is extended to the water underneath and allows the proprietor to make use of it.

Worth noticing are the peculiarities of the common law and civil law traditions that are openly traceable in the two cases. Legal systems of the civil law tradition make a distinction - proper to the Roman law - between public and private waters. The category of public water includes all those waters that are the most important and perennial sources essential to human life, conditioning their use to administrative permission. Private water includes the (relatively) less important sources of water that do not need an administrative permission. ${ }^{26}$ The legal systems of the common law tradition do not have this distinction. However, following the doctrine of riparianism, they maintain "the principle of Roman law that flowing waters are publici juris and [...] that those who have access to such waters may reasonably use them, thus privileging the owners of lands adjacent to watercourses."27

Hence, in both traditions there is some form of public limit on the exploitation of water. In the civil law systems this depends on the publicity of the ownership of the resource. In the common law systems, on the contrary, it is configured as a limit imposed on the ownership of private owners. This is the core distinction that however has to be observed more thoroughly.

23 Philippe Cullet, "Groundwater - Towards a New Legal and Institutional Framework", in P. Cullet et al., Water Conflicts in India - Towards a New Legal and Institutional Framework, Forum for Policy Dialogue on Water Conflicts in India, (2012): 61.

24 C.R. Bijoy, "Kerala’s Plachimada Struggle: A Narrative on Water and Governance Right", cit.: 4338.

25 Ibid.

26 Stephen Hodgson, "Law and Water - The Right Interface”, Development Law Service, FAO Legislative Study, Vol. 84, (2004): 48.

27 Ibid.: 49. 
In the Indian case the public authority - namely the Panchayat - received from the State of Kerala the power of control over the usage of water as a private good. The private owner, pursuant to the legal framework before the introduction of the KGWAct which confirmed and clarified the power of the local authority, has to acquire a permission from the authority if he or she wants to start a pumping activity. Although the KGWAct clarified the framework by stating that "the groundwater is a critical resource of the state," 28 the framework applicable to the case is much blurred and, as pointed out before, relies on a balancing of the principles of Public Trust Doctrine and common law rules on the matter.

Thus, it seems that if the property regime concerning groundwater in India is of difficult qualification, the Italian property regime appear more clearly defined at least at a superficial look. To better compare the two situations, it is thus necessary to conduct a deeper analysis of three core elements of the legal frameworks that constitute the framing corners of the structure. In particular, it is necessary to move beyond the proprietary regime and look at dynamic elements such as: $a$ ) the need (or not) for an act of the public authority to extract water, $b$ ) the existence of limits imposed on the extracting activity, and c) the existence of a price that the private actor has to pay.

a) For what concerns the first element, in both countries the private actor can start an extracting activity of groundwater for commercial purposes only after an act of the competent public authority. In the case of India the local authority gave the licence to the company for its pumping activity. Similarly, in the Italian case Uliveto S.p.A. received a licence from the local municipality to commercially exploit groundwater. In both cases, the public authority has to intervene to authorise the extraction, and the tensions arised when it decided to unilaterally modify some of the elements of the original acts which allowed the private appropriation of the resource.

b) The second element is represented by the limitation imposed upon the extracting activity. In the Italian framework the licence allowing the extracting activity sets forth some limitations concerning the amount of water that can be used, the impact on the environment and on the hydrological equilibrium, etc. ${ }^{29}$ The Indian KGWAct identifies similar limits and empowers the Panchayat to revoke the licence in the event that the extractor does not respect them. However, the Italian case differs from the Plachimada case in that such limitations are the object of the debate. The single judge ruled in favour of the power of the Panchayat to revoke the licence on the ground of those very limitations.

28 Kerala Ground Water (Control and Regulation) Act of 2002, no. 19.

29 See Decreto legislativo October 8, 2011, no. 176, which enforced the EU Directive 2009/54/CE. 
The division bench of the High Court instead ruled against. Some limits seems to exist in the Indian framework, nonetheless their extent and whose power is to apply them is not clear yet in the Plachimada case. The pronouncement of the Supreme Court will hopefully make it clear. ${ }^{30}$

c) The last element taken into account here is the existence of a price that the private actor has to pay for the water used. In the case of Uliveto S.p.A. the law clearly provides for a price that the Company has to pay in proportion to the amount of water used. ${ }^{31}$ The same thing is not present in the arrangement accompanying the licence in the case of Plachimada. This corroborates the vision of groundwater as private property of landowners. It is nonetheless necessary to notice that this difference exists more in principle than in reality. The Italian legal framework recognized that water exploitation needs to be compensated only in few cases. In the others, even though a public property is exploited by privates for commercial purposes, there is no economic offset of such privatization and, even when there is, the price is ridiculously low so that it does not really have an impact on the property arrangement. The effect is a de facto privatization. The Indian legal framework does not provide for any price of groundwater exploitation for commercial purposes in accordance with the private property regime. Nonetheless, it empowers the local authority and the surrounding community with some power of control and standing against the exploitation of the groundwater, which translates in a kind of system of shared and distributed property rights lacking in the Italian legal framework.

Notwithstanding the aforementioned differences, the two legal systems share a common framework in which the water is located and consequently understood. The two legal frameworks - exemplifications of a broader phenomenon $^{32}$ - rely on a similar understanding of ground and bottled water. In both countries the groundwater destined to bottling is understood as an accessory good - of little consideration on its own - linked to the land object of licence. In India, as shown by the divergence between the two decisions, the idea of groundwater as a chattel attached to the land is highly spread. Similarly, in Italy the licence primarily refers to the land given to the private entrepreneur with the aim of allowing her to conduct the extracting activity, and only secondarily the water is considered in itself. Within this framework, the water

30 See Koonan Sujith, "Legal Implications of Plachimada: a Case Study", International Environmental Law Research Centre (2007), http://www.ielrc.org/content/w0705.pdf.

31 See Legge regione Toscana del 2004, no. 38.

32 I argue that the two legal frameworks are part and witness an undergoing process of legal transplants that exports a legal framework that was designed too long ago, when bottled water was a small and restricted phenomenon of negligible importance. 
involved is considered a commercial product ${ }^{33}$ that, within some limits of mode and nature of exploitation, does not raise public, environmental and social concerns.

Furthermore, in both contexts groundwater is not considered as part of the larger category of water but it is treated as something separated and different, disregarding all the concerns that exist around water and its exploitation. Once the licence is granted, the private actor has a considerable sphere of autonomy of action in the exploiting activity.

What is more important is that the adoption of similar legal paradigms has different consequences in the two countries in terms of socio-economic and environmental impacts. In Italy - besides the concern raised by the referendum on the privatization of water services ${ }^{34}$ - the privatization of water raises little concern on the exploitation of water resources due to the relative abundance of such resources (despite the abnormal use of bottled water by the population). ${ }^{35}$ In India it produces significant negative social consequences including water shortage and problems in the access to water for personal use and agriculture.

A consequence of the different underlying scenario is that the Indian context seems to be characterized by a broader and stronger awareness of the importance of the resource. That is because the surrounding communities suffer directly the effects of the pumping activity conducted by the Company but also because of a different consideration of the culture on water. The awareness on the issue and its consequences are far less entrenched in a country like Italy. The Uliveto case witnesses it.

\section{Reconsidering the legal paradigm}

While being aware of the differences that the regulations on bottled and groundwater have in various countries, ${ }^{36}$ the intent of this work - as said before - is to focus the attention on the similar paradigm on which most, if not all, regulations rely in different legal systems to understand which consequences it involves. As

33 See Barlow Maude and Clarke Tony, "Who Owns Water?”, The Nation, Sept 2, 2002.

34 The 2011 Referendum revolved around the question of whether to keep the management of water services public and, therefore, out profit dynamics.

35 Despite the great amount of safe and clean water available in the Italian territory, Italy locates in the first five position for pro-capita consumption of bottled water that amounts to 189 liters per person (Annual Report Bevitalia Beverfood.com: 2013-2014).

36 For a general comparison of the regulation in India see P. Cullet, "Groundwater - Towards a New Legal and Institutional Framework”, cit.: 66-69. 
it has been shown above, the effects of the framework differ not only in the level of intensity but also and mainly in their nature.

Daniel Aguilar, referring to the issue of groundwater regulation in India, points out that the main problem is the linkage of groundwater to land property rights. He affirms that in India "groundwater rights belong only to landowners and can only be transferred when the plot of land is transferred. Thus the poor who cannot afford to buy land are legally incapable of purchasing a right to pump groundwater as well." 37 In his view the solution would be to "separate land rights from water rights, as many other nations do, and make water its own independently tradable commodity. This change would make water available without regard to land ownership." 38

However, this is far from being a solution to the issues concerning bottled and groundwater as this change produces some modification in the details of the regulation but do not modify the way of understanding and looking at the resource, leaving unchanged the common paradigm shaping the matter in most countries. As Philippe Cullet says in relation to the situation in India, it is not sufficient to substitute the common law rules on groundwater with the principle of Public Trust Doctrine. As the author points out, in order to have an actual and implemented regulation that "ensures equitable and environmentally sustainable availability of groundwater [...] it is not enough to simply introduce the principle of public trust to remedy the ills of a system putting most control over groundwater in the hands of bigger landowners and the State. The principle of public trust is not in itself a magic pill against abuse of power by the State in its exercise of its duties as a trustee. This requires many more safeguards." 39 This may be a good starting point needed to break with the precedent regulation, "at the same time, this will only achieve its desired environmental and social goals if the laws adopted ensure that this does not pave the way to another form of privatisation through the setting up of tradable entitlements."40

This last section aims to show that the cause of inequality and environmental unsustainability is not just a matter of technical arrangements of the regulation. The problem lies at a much deeper and fundamental level: it is a problem of misrepresentation of groundwater that produces a distorted understanding of the phenomenon of water bottling and water exploitation. The dimensions of the phenomenon of exploitation of groundwater are enormous,

37 Daniel Aguilar, "Groundwater Reform in India: An Equity and Sustainability Dilemma", Texas International Law Journal, Vol. 46 Issue 3, (Summer 2011): 653.

38 Ibid.

39 P. Cullet, "Groundwater - Towards a New Legal and Institutional Framework", cit.: 71.

40 Ibid. 
the "global consumption of bottled water [which is only one of the main reasons why groundwater is pumped] reached 154 billion liters in 2004"41 and it is considerably increasing since it was "98 billion liters five years earlier." 42 Notwithstanding the paramount role that this phenomenon is assuming, its regulation remains unchanged and unchallenged because of a failure in its understanding. Christine Klein and Ling-Yee Huang "highlight the law's failure to participate in this robust cultural discourse. Moreover, [they] argue that the law has been negligent in its duty to enrich the dialogue and to prod society toward the thoughtful and most efficient use of an essential natural resource." 43 Their proposal relies on four concepts that should "provide a particularly fertile ground for the shaping of cultural water norms [that are] reasonable use, beneficial use, preferred uses, and the public interest." 44

Most of the regulations on ground and bottled water rely on the perception of the water as a good of little - or no - value. As such, private companies, to which this good is given by the public, can transform it into a commodity and subject it to market dynamics. Both the cases analysed in this work witness how the courts as well as the regulations themselves rely on this very assumption. In the Plachimada case the matter revolves around the power of the local authority to limit the exploitation. Similarly, in the Uliveto S.p.A. case the core of the matter is the possibility for the local authority to unilaterally modify the terms and the burdens of the licence. In both cases the exploitation of groundwater conducted by private entities is not discussed and does not amount to an issue as long as it is contained within certain limits. Limits that, as explained before, are far from prevent harms to society and that in the case of India entail problems of "equitable and environmentally sustainable availability of groundwater". 45

The ideological framework behind the exploitation of groundwater and bottling is thus responsible for the production of a commodified image of the resource and for disregarding its very essence, i. e. the fact that water is a scarce resource essential for human life. When proposing a theoretical solution to water commodification, Maude Barlow and Tony Clarke argue that "in a world where everything is privatized, citizens must establish clear perimeters around

41 Emily Arnold, “Bottled Water: Pouring Resources Down the Drain”, Earth Policy Institute, (February 2006): 1.

42 Ibid.

43 Christine A. Klein and Ling-Yee Huang, "Cultural Norms as a Source of Law - The Example of Bottled”, Cardozo Law Review, Vol.30, No.507, (2008): 102, http://scholarship.law.ufl.edu/ facultypub/13

44 Ibid.: 103.

45 D. Aguilar, “Groundwater Reform in India: An Equity and Sustainability Dilemma”, cit.: 653. 
those areas that are sacred to life and necessary for the survival of the planet."46 If some perimeters have shyly been created for some types of water resources, it is not the case for bottled water.

The contrast that is well described by Richard Wilk between a "thriving trade in commoditized water, along side a widespread public perception that water is a public good, a necessity of life that people deserve as a right rather than a privilege" ${ }^{47}$ does not include the category of water that is here analysed. The Italian framework, as many others, does not regulate groundwater in the same way of the other types of water but subjects it to the regulation applied to mines and extracting activity of minerals, a rather different activity concerning resources of totally different nature and importance for human life. ${ }^{48}$

Similarly, the Indian framework provides for a private property arrangement that - if not limited by common claims and, to some extent, denatured of its proprietary right form - understand water as good susceptible of private appropriation in accordance to property rules.

Furthermore by allowing the private exploitation of what is supposed to be a public or 'social resource, 49 this framework, especially in countries where the level of wealth is relatively low, produces the phenomenon of water grabbing, namely "a situation where powerful actors are able to take control of, or reallocate to their own benefits, water resources already used by local communities or feeding aquatic ecosystems on which their livelihoods are based."50

\section{Conclusion}

What comes out from the compared analysis of the two cases and of their legal frameworks is that countries regulate groundwater on the basis of an ideological

46 M. Barlow and T. Clarke, "Who Owns Water?", cit.

47 Richard Wilk, "Bottled Water: the Pure Commodity in the Age of Branding”, Journal of Consumer Culture, Vol.6, Issue No.3, (2006): 307.

48 The Italian Supreme Court (Corte di Cassazione), Decision of April 23, 2001, No.176, declared that mineral and thermal waters destined to bottling, since they cannot by subject of universal consumption, do not fall within the general category of public water and the administrative judge have jurisdiction on the relative controversies.

49 The term "social resource" is used to identify a category of resources on which communities (as something different from, and yet not opposed to, the some of individuals) do have legitimate claims.

50 Lyla Mehta, Gert J. Veldwisch and Jennifer Franco, "Introduction to the Special Issue: Water Grabbing? Focus on the (Re)appropriation of Finite Water Resources”, Water Alternatives, Vol.5, No. 2, (2012): 197. 
misrepresentation of the resource. This framework disregards the aspect of essentiality of the resource for human life impacting on the proprietary arrangements applied. Reconsidering the way to look at the resource, by acknowledging its importance for human life and the environment as well as its scarcity, is the only way in which proprietary arrangements can be properly assessed. The analysis of the Indian and the Italian cases showed how in both situations issues concerning groundwater largely disregard the important on-going debate and concern on water resources with no apparent reason.

Bottled water regulations rely on a tension. On the one hand, water is a natural resource essential for human life of which the world is running short. The most evocative legal framework promoted along this line is the human right of access to water. ${ }^{51}$ At the same time, once water is destined to bottling it is considered a commodity subjected to market dynamics. This aspect is most clearly evident through the application of the mining regulations to water extraction for bottling purposes in a significant number of legal systems. ${ }^{52}$ These regulations have typically been designed for the commercial exploitation of raw resources of no relevance but for their commercial value.

Accordingly, after a reconceptualization of the resource is done by taking into consideration the underpinning tension, a reconfiguration of the property regime applied should follow. In both cases the courts already acknowledge or perceive the need of articulate a regime that takes into account public instances and the concerns pertaining to the local communities involved.

My proposal is to entitle the communities that rely on the resource ${ }^{53}$ with legitimate claims against private exploitations that threaten their previous and common use. Claims that derive from the essential nature of the resource and that involve a liability of the State for the management of the resource should be made easier to file. The property regime should be reassessed in order to strengthen the public nature of the good, though complemented by a local coordination for a closer consideration of the peculiarities that each case presents.

From a substantive point of view, the possibility to commercially exploit a particular water resource should, in fact, depend on the social relevance of such source. Thus, the State should look at the diffused and local interests when

51 Declared by the United Nations (UN), in the Resolution GA/10967.

52 See, e.g., the UE Directives regulating bottled water (Directive n. 80/777/CEE and the following Directive No.09/54/UE) provides for the application of the regulation on mines to bottled water extraction and exploitation.

53 See F. Berkes, “Community-Based Conservation in a Globalized World”, Proceedings of the National Academy of Sciences, Vol.104, No.39, (2007): 15188-93. 
granting a licence for the private exploitation. From a procedural perspective, the public procedure evaluating the opportunity of the licence released should involve the resource-based community, ${ }^{54}$ the one more able to understand the particular instances, in order to tailor the final regulation of the licence on the specific context.

At the same time, the proprietary structure needs to be clearly affirmed at the more general level of the State to avoid individual or local corruption. Furthermore, in order to be a completely coherent framework, it should provide that the recognition of these water resources as a public property is followed by the right of the State to a proportioned quid pro quo when such resource, provided that the access to it of the surrounding community is not jeopardized, is given to privates for commercial purposes.

\section{References}

Aguilar, Daniel. Summer 2011. Groundwater Reform in India: An Equity and Sustainability Dilemma. Texas International Law Journal 46 (3):623-653.

Arnold, Emily, and Larsen Janet. 2006. Bottled Water: Pouring Resources Down the Drain. Earth Policy Institute, February 2. Accessed October 28, 2015. http://www.earth-policy.org/ plan_b_updates/2006/update51.

Barlow, Maude, and Clarke Tony. 2002. Who Owns Water?. The Nation, September 2. Accessed October 28, 2015. https://www.thenation.com/article/who-owns-water.

Berkes, F. 2007. Community-Based Conservation in a Globalized World. Proceedings of the National Academy of Sciences 104 (39):15188-15193.

Bijoy, C.R. 2006. Kerala's Plachimada Struggle: A Narrative on Water and Governance Right. Economic and Political Weekly 41 (41):4332-4339.

Cullet, Philippe. 2012. Groundwater - Towards a New Legal and Institutional Framework. In Water Conflicts in India - Towards a New Legal and Institutional Framework, edited by P. Cullet et al. Pune: Forum for Policy Dialogue on Water Conflicts in India, 58-71.

Garduño, Héctor, Romani Saleem, Sengupta Buba, Tuinhof Albert, and Davis Richard. 2011. India Groundwater Governance - Case Study. Water Papers, June. Accessed October 28, 2015. https://www.worldbank.org/water.

Hodgson, Stephen. 2004. Law and Water - the Right Interface. Development Law Service, FAO Legislative Study 84. pages 120.

Jananeethi. 2002. Report on the Amplitude of Environmental and Human Rights Ramifications by the HCCBPL at Plachimada. (Thrissur: Jananeethi, July 2002).

Klein, Christine A., and Huang Ling-Yee. 2008. Cultural Norms as a Source of Law - The Example of Bottled. Cardozo Law Review 30 (507):101-146. http://scholarship.law.ufl.edu/ facultypub/13.

54 Ibid. 
Koonan, Sujith. 2007. Legal Implications of Plachimada: A Case Study. International Environmental Law Research Centre (IELRC). Accessed October 28, 2015. http://www.ielrc. org/content/w0705.pdf.

Koonan, Sujith. 2010. Groundwater: Legal Aspects of the Pachimada Dispute. In Water Governance in Motion: Towards Socially and Environmentally Sustainable Water Laws, edited by P. Cullet et al. New Delhi: Cambridge University Press, 159-198.

Koonan, Sujith. 2011. Constitutionality of the Plachimada Tribunal Bill, 2011: An Assessment. Law, Environmental and Development Journal 7 (2):151.

Mehta, Lyla, J. Veldwisch Gert, and Franco Jennifer. 2012. Introduction to the Special Issue: Water Grabbing? Focus on the (Re)Appropriation of Finite Water Resources. Water Alternatives 5 (2):193-207.

Shaji, K. A. 2015. Centre terms Plachimada Bill Unconstitutional. The Hindu, January 20. Accessed October 28, 2015. http://www.thehindu.com/todays-paper/tp-national/ tp-andhrapradesh/plachimada-victims-resent-centres-action/article6733966.ece.

Singh, Chhatrapati. 1991. Water Rights and Principles of Water Resource Management. Bombay: N.M. Triphati.

Wilk, Richard. 2006. Bottled Water: The Pure Commodity in the Age of Branding. Journal of Consumer Culture 6 (3):303-325. 